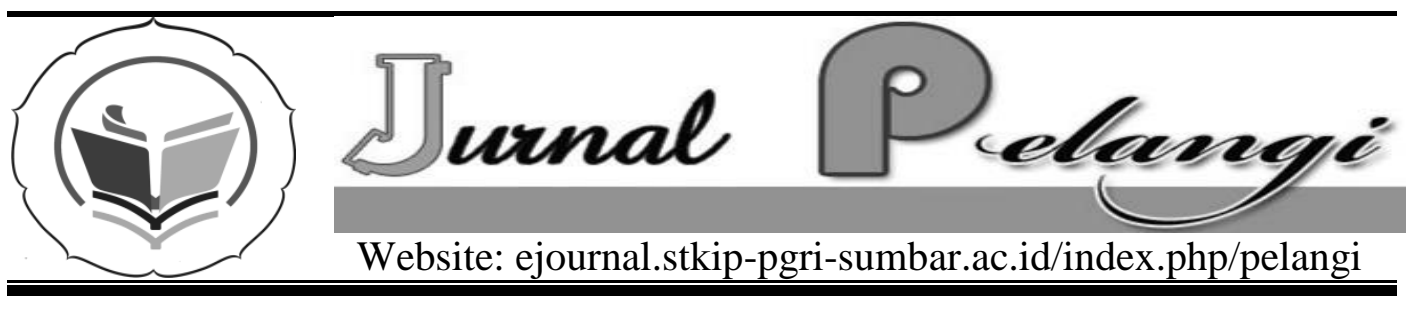

\title{
PERAN GURU BK/KONSELOR DALAM PENCEGAHAN TINDAKAN BULLYING DI SEKOLAH
}

\author{
Hengki Yandri \\ STKIP PGRI Sumatera Barat \\ hengki@konselor.org
}

\section{INFO ARTIKEL}

Diterima :01-01-2014

Disetujui :01-12-2014

Kata Kunci:

Peran guru

BK/Konselor, Bullying
Keywords:

counselor role, bullying

\section{Abstrak}

Bullying merupakan istilah untuk tindakan kekerasan atau penindasan yang dilakukan oleh pihak yang lebih kuat baik dari segi umur, kekuatan, kekuasaan kepada pihak yang lemah. Bentuk dari perilaku bullying yaitu bullying fisik, bullying verbal dan bullying mental/psikologis yang dapat ber dampak buruk kepada korbannya, seperti lebam, luka, sakit, penakut, dan lain sebagainya dan untuk jangka panjang yaitu terganggunya kondisi psikologis dan penyesuaian sosial yang buruk. Guru Bimbingan dan Konseling/Konselor memiliki peranan penting dalam mencegah dan menanggulangi bullying di sekolah, untuk itu diperlukan pelayanan yang efisien dan komprehensif ke pada seluruh siswa dengan menggunakan berbagai keterampilan dan media yang dapat membantu kinerja guru BK/Konselor dalam menangani bullying.

\section{Abstract}

Bullying is a term for the act of violence or oppression of the more powerful party in terms of age, strength, power to the weak. form of bullying behavior that is physical bullying, verbal bullying and mental bullying / psychological that may adversely affect the sacrifice, such as bruises, cuts, pain, timid, and so forth, and in the long run that is impaired 'psychological and social adjustment that bad. Counselors have an important role in preventing and tackling bullying in schools, for it required a comprehensive and efficient service to all students, with various skills and media that can help the performance of Counselors in addressing bullying 


\section{PENDAHULUAN}

Sekolah merupakan salah satu institusi yang menjadi ujung tombak keberhasilan atau kegagalan pencapaian tujuan pendidikan nasional. Pendidikan bertujuan untuk mengembangkan potensi peserta didik sehingga menjadi manusia yang beriman dan bertakwa, berakhlak mulia, sehat, berilmu, cakap, kreatif, mandiri dan menjadi warga negara yang bertanggungjawab (UU No. 20 tahun 2003: Pasal 3). Untuk bisa mewujudkan itu, tentunya banyak faktor yang mempengaruhi kelancaran pelaksanaan program pendidikan di sekolah. Apalagi sekolah sebagai wadah yang menampung beragam peserta didik dari berbagai latar belakang berbeda, hal ini memungkinkan mereka membawa berbagai permasalahan ke sekolah yang akan mengganggu kegiatan belajarnya.

Masalah yang sering diberitakan di media masa seperti tauran antar pelajar, guru memukul peserta didik, senior menindas junior, pelecehan seksual, senior menghukum junior dengan push up dan masih banyak lagi yang lainnya. Semuanya itu termasuk dalam kategori tindakan bullying.Bullying merupakan sebuah situasi di mana terjadinya penyalahgunaan kekuasaan/kekuatan yang dilakukan oleh seseorang/kelompok (Yayasan Semai Jiwa Insani, 2008). Menurut Beane (2008:2) "The term bullying describes wide range of behaviors that can have an impact on a person's property, body, feelings, relationships, reputation and social status". Istilah bullying menggambarkan berbagai perilaku yang dapat berdampak pada kepemilikan seseorang, fisik, perasaan, hubungan, reputasi dan status sosial. Korban bullying biasanya tidak memiliki daya atau kekuatan untuk membela atau mempertahankan dirinya karena lemah secara fisik atau mental, hal ini akan memicu terjadinya stres karena rasa takut yang luar biasa.

Seperti yang terjadi di SMA 90 Jakarta pada hari senin tanggal 1 Desember 2008, siswa kelas 1 dipaksa membuka bajunya, push up, lari mengelilingi lapangan dan ditampar oleh seniornya. Kejadian ini membuat korban bullying mengalami memar di pelipis dan luka pecah bibir, kemudian secara psikologis korban bullying biasanya akan mengalami trauma untuk sekolah. Selanjutnya kejadian bullying di SMA 82 Jakarta hari Selasa tanggal 3 November 2009, seorang siswa kelas 1 dipukul oleh senior kelas 3 sebanyak 30 orang sampai siswa kelas 1 pingsan dan dirawat di rumah sakit. Kemudian pada hari Sabtu tanggal 17 Februari 2010 di SMA 46 Jakarta terjadi tindakan bullying yang dialami oleh siswa kelas 1 yang dianiaya oleh siswa kelas 3. Korban bullying diperlakukan tidak sopan oleh seniornya seperti meludahi, menendang motor korban dan lebih parahnya korban bullying dipukul 
pakai helm, ditendang di punggung, dan lima sundukan rokok di lengan kanannya. Hal ini membuat korban trauma dan memilih untuk home schooling. Seterusnya kejadian bullying di SMA 70 Jakarta yang terjadi pada bulan April 2010, korban bullying dianiaya hanya karena tidak memakai baju kaos dalam saat ke sekolah, korban bullying di pukuli hingga lebam ditubuhnya. Kemudian pada hari Kamis pada tanggal 27 Juli 2012 terjadi kasus bullying di SMA Don Bosco Pondok Indah Jakarta. Korban bullying dipukul dan disundut rokok oleh seniornya (Sumber: http://forum.detik.com)

Kasus bullying yang dimuat di detik.com hanya sebagian kecil yang sudah terungkap, karena masih banyak kejadian bullying terjadi di sekolah-sekolah yang belum terungkap atau muncul ke publik. Kasus bullying yang banyak terungkap adalah bullying yang bersifat fisik, sebab dampaknya bisa langsung terlihat sedangkan yang bersifat psikis dan verbal sulit untuk dilacak atau dilihat dampaknya secara nyata. Hal ini ditunjang dengan penelitian yang dilakukan oleh Dorothy Espelage, mengungkapkan bahwa fenomena bullying telah menggejala secara umum pada siswa. Perilaku bullying dilakukan antar sesama mereka da nada juga yang ikut-ikutan. Artinya, mereka dipaksa oleh temannya karena takut untuk melawan kehendak kelompok gengnya. Selanjutnya sebuah penelitian yang dilakukan oleh Tonja Nasel dkk, terungkap bahwa sebanyak $17 \%$ siswa menjadi korban bullying dan $19 \%$ mengaku menjadi pelaku bullying terhadap temannya, kemudian $6 \%$ yang melaporkan menjadi pelaku sekaligus korban bullying (Ida Novianti, 2008:2).

Jika tindakan bullying ini terus dibiarkan, maka besar kemungkinan tujuan pendidikan yang tertera di Undang-Undang Republik Indonesia akan sangat sulit dicapai, untuk itu dibutuhkan kerja sama dari berbagai pihak untuk memberantas atau mencegah tindakan bullying seperti pemerintah, masyarakat, pihak sekolah, orangtua, dan siswa. Salah satu pihak sekolah yang sangat berperan dalam mencegah dan mengentaskan tindakan bullying yaitu guru BK/Konselor. Guru $\mathrm{BK} /$ Konselor mempunyai peran penting dalam menanggulangi atau mencegah tindakan bullying di sekolah. Oleh sebab itu, guru BK perlu menangani secara komprehensif dan sistematis untuk mencegah dan mengentaskan tindakan bullying di sekolah.

\section{KARAKTERISITIK PERILAKU} BULLYING

Ada empat unsur yang terdapat dalam bullying dan selalu melibatkan tiga unsur yaitu (1) ketidakseimbangan kekuatan, (2) niat untuk menciderai, (3) ancaman agresi lebih lanjut,, (4) teror (Colorosa, 2007). Bullying bisa saja dilakukan 
oleh orang yang lebih tua, lebih besar, dan lebih kuat karena bullying bukan perkelahian yang melibatkan dua pihak yang memiliki kekuatan seimbang. Perilaku bullying biasanya menyebabkan timbulnya kepedihan emosional, luka fisik, dan bisa keduaduanya (kepedihan emosional dan luka fisik). Pelaku akan merasa senang ketika melihat korban menderita. Bullying tidak terjadi hanya sekali, pelaku dan korban mengetahui bahwa tindakan bullying itu bisa terjadi berulang-ulang, tanpa henti dan semakin meningkat, jika semua hal itu terjadi maka akan muncul teror. Ketika teror yang dilancarkan oleh pelaku bullying tepat mengenai korbannya maka teror bukan hanya menjadi cara untuk mencapai tujuannya, sekali teror tercipta, pelaku bullying dapat bertindak tanpa merasa takut adanya pembalasan dari korbannya

Tindakan bullying mempunyai tiga karakteristik yang terintegrasi yaitu: (1) adanya perilaku agresi yang menyenangkan pelaku untuk menyakiti korban, (2) tindakan itu dilakukan secara tidak seimbang sehingga menimbulkan rasa tertekan pada korban, dan (3) perilaku itu dilakukan secara berulang dan terus-menerus (Rigby dalam Astuti, 2008:4). Pelaku bullying biasanya akan sangat senang apabila melihat target atau korbannya menderita olehnya, mereka akan merasa memiliki kepuasan batin atau kesenangan hati apabila dapat menyakiti korbannya. Biasanya pelaku bullying adalah orang atau sekelompok orang yang lebih kuat, dalam artian tindakan bullying dilakukan secara tidak seimbang sampai korban bullying merasa tertekan, sehingga pelaku bullying bisa melakukannya secara berulangulang dan terus menerus.

Karakteristik anak yang rentan menjadi korban bullying yaitu, (1) anak yang baru di lingkungannya; (2) anak termuda di sekolah; (3) anak yang pernah mengalami trauma; (4) anak penurut; (5) anak yang perilakunya dianggap mengganggu orang lain; (6) anak yang tidak mau berkelahi; (7) anak yang pemalu; (8) anak yang miskin atau kaya; (9) anak yang ras suku etnisnya dipandang inferior oleh pelaku; (10) anak yang agamanya di pandang inferior oleh pelaku; (11) anak yang cerdas, berbakat atau memiliki kelebihan; (12) anak gemuk atau kurus; (13) anak yang memiliki ciri fisik yang berbeda dengan orang lain; dan (14) anak yang berada di tempat yang keliru pada saat yang salah (Colorosa, 2007).

\section{BENTUK-BENTUK PERILAKU YANG DIKATEGORIKAN BULLYING}

Secara umum, bullying dapat dikelompokkan pada tiga kategori yaitu, (1) bullying fisik, (2) bullying verbal, dan (3) bullying mental/psikologis. Bullying fisik merupakan jenis bullying yang bisa dilihat secara kasat mata. Siapapun 
bisa melihatnya karena terjadi sentuhan fisik antara pelaku bullying dengan korbannya, seperti: memukul, mendorong, mencekik, menggigit, menampar, menendang, meninju, mengunci seseorang dalam ruangan, mencubit, merusak pakaian/property pribadi, mencakar, menodongkan senjata, menginjak kaki, melempar dengan barang, meludahi, menghukum dengan cara push up, menarik baju, menjewer, menyenggol, menghukum dengan cara membersihkan WC, memeras dan merusak barang orang lain (Yayasan Semai Jiwa Insani, 2008).

Kata-kata adalah alat yang kuat dan dapat mematahkan semangat seseorang yang menerimanya. Bullying verbal merupakan bentuk bullying yang paling umum digunakan, baik oleh anak laki-laki maupun oleh anak perempuan. Bullying verbal mudah dilakukan dan dapat dibisikkan di hadapan orang dewasa atau teman sebaya tanpa terdeteksi. Bullying verbal dapat berupa julukan nama, celaan, fitnah, penghinaan dan pernyataanpernyataan bernuansa ajakan seksual atau pelecehan seksual, menuduh, menyoraki, memaki, mengolok-olok, menebar gosip. Selain itu, dapat berupa menakuti lewat telepon, $e$ mail yang mengintimidasi dan "suratsurat kaleng" yang berisi ancaman kekerasan (Colorosa, 2007).

Bullying mental/psikologis yang paling berbahaya karena sulit dideteksi dari luar. Seperti: memandang dengan sinis, menjulurkan lidah, menampilkan ekspresi wajah yang merendahkan, mengejek, memandang dengan penuh ancaman, mempermalukan di depan umum, mengucilkan, memandang dengan hina, mengisolir, menjauhkan, dan lain-lain (Yayasan Semai Jiwa Insani, 2008).

\section{FAKTOR PENYEBAB BULLYING}

Banyak faktor yang mempengaruhi terjadinya bullying. Beane (2008:23) menjelaskan kemungkinan penyebab terjadinya bullying yaitu (1) physical influences, (2) biological factors, temperament, (4) social influences, (5) learned preferences, (6) belief in one's own superiority, (7) violence, aggression, and conflict in the media, (8) sport violence, (9) prejudice, (10) jealousy, (11) protecting one's image, (12) fear, (13) self-centeredness, lack of sensitivity, and desire for attention, (14) group mentality, (15) poor family environment, (16) never being told not bully, (17) poor self-esteem, (18) reaction to tension, (19) seeing aggression allowed and rewarded, (20) desire for control and power, (21) poor neighborhood and community values, (22) poor school environment. Anak-anak yang memiliki kekurangan secara fisik cenderung menjadi korban bullying seperti anak-anak yang badannya terlalu gemuk, anak yang tinggi badannya tidak sama dengan teman-temannya yang lain seperti badan yang pendek, anak yang cacat 
dan sebagainya. Faktor biologis juga bisa menjadi salah satu penyebab anak menjadi korban bullying seperti anak yang memiliki silsilah keturunan bisu, teman-temannya akan mengolokoloknya karena ia berbeda dengan yang lainnya. Lingkungan mempengaruhi perkembangan anak, mereka banyak belajar dari lingkungan seperti lingkungan keluarga, sekolah, sosial dan masyarakat. Jika anak dibesarkan di lingkungan yang buruk dan sudah menganggap biasa kejadian bullying, maka kecenderungan anak akan meniru dan tindakan/perilaku yang ditampilkan di lingkungan sosialnya karena hal ini akan memungkinkan si anak ingin mempelajari bullying dalam artian ingin tahu lebih banyak tentang bullying sehingga membuat mereka mencoba untuk melakukannya.

Pada kalangan remaja, jika mereka bisa menunjukkan kekuatannya secara fisik kepada temannya, maka ia dianggap kuat. Anak-anak seperti ini biasanya meyakini bahwa dengan menunjukkan kekuatannya itu mereka memiliki keunggulan dari teman-temannya. Salah satu penyebab anak-anak seperti itu karena pengaruh media massa yang menampilkan kekerasan, agresi dan konflik sehingga anak-anak belajar dari media tersebut, seperti kekerasan yang terjadi pada olah raga yang sering menampilkan tindakan anarkis, secara tidak langsung anak-anak belajar dari kejadian yang ditampilkan tersebut. Selanjutnya salah satu yang dapat menyebabkan bullying yaitu cemburu dan prasangka yang salah terhadap seseorang atau suatu kelompok sehingga memicu timbulnya tindakan kekerasan atau bullying kepada kelompok tersebut, hal itu dilakukan untuk menyembunyikan kekurangan yang dimilikinya.

Anak-anak yang penakut sangat rentan menjadi korban bullying karena mereka tidak bisa melindungi diri mereka dari serangan pelaku bullying. Anak yang memiliki egosentris, kurang sensitif terhadap orang lain dan lingkungan serta kurang mendapat perhatian biasanya akan cenderung menjadi pelaku bullying, karena mereka menilai dari sudut pandang mereka sendiri, sehingga mereka tidak sensitif terhadap orang lain dan lingkungan mereka. Kelompok anak-anak yang pintar biasanya akan menindas anak-anak yang kurang dari mereka karena mereka merasa memiliki kekuatan/kelebihan yang tidak dimiliki orang lain sehingga dengan kelebihannya itu mereka menggunakan untuk menindas orang lain yang memiliki self-esteem yang rendah.

Selanjutnya Riauskina dkk (2005) mengemukakan bahwa ada beberapa penyebab terjadinya bullying di sekolah yaitu (1) perilaku bullying merupakan tradisi turun-temurun dari senior (senioritas), (2) balas dendam karena dulu pernah diperlakukan sama (menurut korban laki-laki), (3) ingin menunjukkan kekuasaan, (4) 
marah karena korban tidak berperilaku sesuai dengan yang diharapkan, (5) mendapatkan kepuasan (menurut korban perempuan), (6) perilaku dianggap tidak sopan menurut ukuran kelompok tertentu. Ada juga korban yang mempersepsikan dirinya sendiri menjadi korban bullying karena berpenampilan norak, tidak berperilaku sesuai dengan kelompok/komunitas, perilaku dianggap tidak sopan dan tidak sesuai dengan tradisi.

\section{DAMPAK BULLYING}

Salah satu dampak bullying yang paling jelas terlihat adalah kesehatan fisik, seperti luka, lebam, sakit kepala, sakit tenggorokan, flu, batuk, sakit dada dan bahkan kematian. Dampak lain yang kurang terlihat, namun memiliki efek jangka panjang yaitu terganggunya kondisi psikologis dan penyesuaian sosial yang buruk.

Gejala-Gejala dampak dari perilaku bullying yaitu, (1) mengurung diri (school phobia), (2) menangis, (3) meminta pindah sekolah, (4) konsentrasi anak berkurang, (5) prestasi belajar menurun, (6) tidak mau main atau bersosialisasi, (7) suka membawa barang-barang tertentu (sesuai permintaan pelaku), (8) anak jadi penakut, (9) marah-marah, (10) gelisah, (11) berbohong, (12) melakukan perilaku bullying kepada orang lain, (13) memar/lebam-lebam, (14) tidak bersemangat, (15) menjadi pendiam, (16) sensitif, (17) rendah diri, (18) menyendiri, (19) menjadi kasar dan pendendam, (20) ngompol, (21) berkeringat dingin, (22) tidak percaya diri, (23) mudah cemas, (24) cengeng (bagi yang masih kecil), (25) mimpi buruk dan mudah tersinggung (Yayasan Semai Jiwa Insani, 2008).

CIRI-CIRI SISWA YANG DAPAT MENJADI KORBAN BULLYING Menurut Soendjojo (www.tabloid-nakita.com) ada beberapa faktor yang menyebabkan siswa menjadi korban bullying yaitu siswa yang belum mampu bersikap assertive sehingga mereka tidak dapat menolak saat diperlakukan negatif, karena ketidakmampuan mereka merespon perilaku bullying. Berdasarkan penelitian Bernstein dan Waston pada tahun 1997 (dalam Rudi, 2010), disimpulkan bahwa karakteristik eksternal korban sasaran tindakan bullying adalah anak yang cenderung lebih kecil atau lebih lemah daripada teman sebayanya.

Selanjutnya Colorosa (2007:95) menyebutkan beberapa karakteristik anak yang rentan menjadi korban bullying yaitu: (a) anak yang baru di lingkungannya; (b) anak termuda di sekolah; (c) anak yang pernah mengalami trauma; (d) anak penurut; (e) anak yang perilakunya dianggap mengganggu orang lain; (f) anak yang tidak mau berkelahi; (g) anak yang pemalu; (h) anak yang miskin atau kaya; (i) anak yang ras suku etnisnya dipandang inferior oleh pelaku; (j) 
anak yang agamanya di pandang inferior oleh pelaku; (k) anak yang cerdas, berbakat atau memiliki kelebihan; (1) anak gemuk atau kurus; (m) anak yang memiliki ciri fisik yang berbeda dengan orang lain; dan (n) anak yang berada di tempat yang keliru pada saat yang salah.

\section{PERAN GURU BK/KONSELOR MENCEGAH TINDAKAN BULLYING}

Bullying sebagai salah satu masalah besar yang harus dicegah karena dapat menimbulkan trauma pada korbannya sehingga membuat kehidupan korban bullying menjadi tidak efektif dan siswa yang menjadi pelaku bullying perlu digali lebih dalam lagi apa yang latar belakangnya melakukan bullying sehingga guru $\mathrm{BK} /$ Konselor bisa mengambil tindakan yang tepat untuk penanggulangan permasalahan bullying.

Untuk itu, guru BK/Konselor perlu memberikan pelayanan konseling yang optimal dan komprehensif sesuai kebutuhan siswa dengan menyediakan program BK yang cocok untuk penanggulangan bullying seperti menyelenggarakan layanan orientasi, layanan informasi, layanan penempatan penyaluran, layanan penguasaan konten, layanan konseling perorangan, layanan bimbingan kelompok, layanan konseling kelompok, layanan konsultasi, layanan mediasi dan layanan advokasi (Prayitno, 2009:45).
Kemudian guru BK/Konselor bisa membuat modul untuk pencegahan bullying di sekolah, membuat model konseling untuk korban bullying, membuat kegiatan konseling teman sebaya, dan lain sebagainya.

Strategi pelayanan konseling yang dapat diperhatikan konselor dalam mengatasi permasalahan bullying di sekolah berdasarkan penelitian yang dilakukan Olweus dkk (Amirah Diniaty, 2012:149) yaitu: (1) make sure an adult known what is happening to their children, (2) make it clear that bullying is never acceptable, (3) recognize that bullying can occur at all levels within the hiorachy of the school, (4) hold a school conference day or forum devoted to buly/victim problems, (5) increase adult supervision in the yard, halls and washrooms, more virgilanty, (6) emphasize caring, respect and safety, (7) emphasize consequences for aggressive behaviors, (8) improve communication among school administrator, teachers, parents, and students, (9) have a school problem box where kids can report problems, concerns and offer suggestion, (10) teach cooperative learning activities, (11) help bullies with anger control and the development of empathy, (12) encourage positive peer relation, (13) offer a variety of extracurricular active which appeal to a range of interests, (14) teach your child to defend himself verbally and phsysically, if necessary, (15) keep 
and mind the range of possible causes: ex. Medical. Psychiatric, Psychological, development, family problem, etc.

Berdasarkan penjelasan di atas, dapat disimpulkan bahwa guru BK/Konselor dalam konteks menjalankan perannya di sekolah harus menyediakan pelayanan yang baik dan optimal untuk seluruh siswa sesuai dengan tanggungjawabnya serta merencanakan layanan sesuai dengan kebutuhan siswa di sekolah, sehingga dengan demikian pelayanan yang diberikan kepada siswa bisa tepat sasaran dan berefek pada perubahan tingkal laku siswa ke arah yang lebih baik. Guru BK/Konselor juga perlu melakukan kolaborasi yaitu melakukan pendekatan-pendekatan untuk mengambil kebijakan dalam mencegah perilaku bullying sehingga perilaku bullying tidak terjadi lagi di sekolah. Pelaku bullying perlu diberikan perhatian dan empati disamping kontrol dan meminimalkan peluang-peluang terjadinya penindasan. Selain itu, guru BK/Konselor perlu melakukan kerjasama dengan berbagai pihak seperti kepala sekolah, wakil kepala sekolah dan guru mata pelajaran serta orang tua. Hal ini penting, agar koordinasi dan suvervisi terhadap pencegahan dan pengentasan bullying benar-benar terjalin sehingga bullying tidak membudaya dan tidak dianggap biasa lagi oleh siswa di sekolah.

\section{KESIMPULAN}

Berdasarkan uraian terdahulu bisa disimpulkan bahwa bullying merupakan masalah yang serius yang dapat mengakibatkan trauma bagi para korbannya, baik secara psikologis, fisik, sosial dan akademis. Banyak faktor yang dapat menyebab terjadinya bullying, jika dikelompokkan secara umum maka dapat dibagi menjadi tiga bagian yaitu latar belakang keluarga, pribadi individu dan lingkungan sekitar seperti sekolah, masyarakat, teman dan sosial.

Bullying dapat terjadi dalam berbagai bentuk yaitu fisik, verbal dan psikologis/mental. Semua bentuk bullying tersebut akan berdampak negatif kepada korbannya. Dampak yang terlihat jelas yaitu bullying fisik, karena bisa dilihat langsung seperti lebam, luka, sakit, dan lain sebagainya. Sedangkan bullying verbal dan psikologis akan terlihat pada jangka panjang yaitu terganggunya kondisi psikologis dan penyesuaian sosial yang buruk.

Dari paparan di atas, makadiharapkankepada guru $\mathrm{BK} /$ Konselor untuk berperan dalam mencegah dan mengentaskan perilaku bullying yang ada di sekolah. Beberapa peran guru BK/Konselor yaitu memberikan pelayanan kepada siswa sesuai dengan kebutuhannya secara optimal dan efisien. Kemudian melakukan kalobarasi dengan orangtua, kepala sekolah, wakil kepala sekolah, guru mata pelajaran 
dan termasuk warga sekolah di sekitarnya untuk menyediakan pengawasan yang baik untuk siswa sehingga sikap dan perilakunya dapat dikontrol.

\section{UCAPAN TERIMAKASIH}

Terbitnya tulisan ini tidak terlepas dari bantuan berbagai pihak, untuk itu penulis ucapkan terima kasih yang sebesar-basarnya kepada Pihak STKIP PGRI Sumatera Barat khususnya pengelola jurnal Pelangi yang telah memberikan kesempatan kepada penulis untuk menulis dijurnal Pelangi. Selanjutnya penulis juga berterima kasih kepada para penyumbang sumber insirasi yang telah memerikan inspirasi bagi penulis untuk mengutip atau menggunakan tulisannya $\mathrm{s}$ bagai bahan referensi.

\section{DAFTAR RUJUKAN}

Amirah Diniyati. 2012. Bullying Versus Tantrum sebagai Perilaku Agresif pada Anak dan Aplikasi Konseling dalam Mengatasinya. Prosiding Seminar Internasional Bimbingan dan Konseling. Padang, 14 Januari 2012.

Astuti, R. P. 2008. Meredam Bullying (3 Cara Efektif Mengatasi Kekerasan pada Anak). Jakarta: Grasindo.

Beane, A. L. 2008. Protect Your Child From Bullying. San Fransisco: Jossey-Bass.
Colorosa, B. 2007. Stop Bullying (Memutus Rantai Kekerasan Anak dari Prasekolah Hingga SMU). Jakarta: Ikrar Mandiri Abadi.

Ida Novianti. 2008. "Fenomena Kekerasan di Lingkungan Pendidikan". Jurnal Pemikiran Alternatif Pendidikan. Vol. 13 (2): 324 338.

Prayitno. 2009. Wawasan Profesional Konseling. Padang: UNP.

Riauskina dkk. 2005. "Gencetgencetan" di Mata Siswa/Siswi Kelas 1 SMA: Naskah Kognitif Tentang Arti, Skenario, dan Dampak "Gencet-Gencetan". Jurnal Psikologi Sosial, 12 (01): 1 13.

Rudi, T. 2010. "Informasi Perihal Bullying”. E-book Indonesia Anti Bullying. Edisi Maret 2010.

Soendjojo, R. P. 2009. Siapa Berpotensi Menjadi Korban Bullying?. Diunduh di http://www.tabloid-nakita.com tanggal 25 Maret 2012.

Undang-Undang Republik Indonesia Nomor 20 tahun 2003 tentang Sistem Pendidikan Nasional. Jakarta: Sekretariat Jenderal Departemen Pendidikan Nasional.

Yayasan Semai Jiwa Insani. 2008. Bullying: Mengatasi Kekerasan di Sekolah dan 
Lingkungan. Jakarta:

Grasindo.

— 2012. Ini Dia 5 Kasus Bullying SMA di Jakarta. Diunduh di http://forum.detik.com tanggal 31 Oktober 2013. 